6.

HISTORIA DEL DERECHO EUROPEO Y CHILENO 



\title{
LA CRÍTICA CONSERVADORA AL DISCURSO DE LOS DERECHOS HUMANOS DE LA “DECLARACIÓN” FRANCESA DE 1789
}

[The Conservative Critique to the Human Rights Discourse of the 1789 French "Declaration"]

\author{
Julio Alvear Téllez* \\ Universidad del Desarrollo, Santiago, Chile
}

\begin{abstract}
RESUMEN
La Declaración de los derechos del hombre y del ciudadano dada en Francia el 20 de agosto de 1789 posee un alto valor simbólico para la teoría política moderna y para el despliegue del discurso histórico de los derechos humanos. Sin embargo, desde su génesis, la doctrina que le inspira fue altamente cuestionada por la filosofía política convencionalmente rotulada como "conservadora". En este artículo se analizan las razones de dicho cuestionamiento, prolongando el problema al relato contemporáneo de los derechos humanos.
\end{abstract}

Palabras clave

Conservadurismo político - Derechos humanos - "Declaración" francesa de 1789.

\section{ABSTRACT}

The French Declaration of the Rights of Man and of the Citizen of August $20^{\mathrm{th}}$, 1789 , has a great symbolic value for the Modern political theory and for the display of the historical discourse on human rights. Nonetheless, from its beginning, the doctrine at the basis of the inspiration was highly challenged by the political philosophy which conventionally labeled it as "conservative". This article analyses the reasons for questioning said doctrine, thus extending the problem to the the contemporaneous account of human rights.

$$
\begin{gathered}
\text { KeYwords } \\
\text { Political Conservatism - Human } \\
\text { Rights - 1789 French "Declaration". }
\end{gathered}
$$

RECIBIDO el 24 de noviembre y ACEPTADO el 7 de diciembre de 2015

* Doctor en derecho por la Universidad Complutense de Madrid. Profesor de derecho político y constitucional en la Facultad de Derecho de la Universidad del Desarrollo. Dirección Postal: Av. La Plaza 680, Las Condes, Santiago de Chile. Correo electrónico: jalvear@udd.cl 


\section{ANTECEDENTES}

Con la universalización del constitucionalismo liberal-socialdemócrata en las últimas décadas, poco se sabe de la lectura "conservadora" de la Déclaration des droits de l'Homme et du Citoyen del 20 de agosto de 1789 (en adelante, la Declaración ${ }^{1}$ ). Pareciera ser que nunca existió una filosofía de la sospecha contra la Declaración, y, más en general, contra el discurso moderno de los derechos del hombre?

En este contexto, los dos grandes mitos que la historiografía republicana tejió en torno al significado de la Gran Revolución, y que justificarían la Declaración de 1789, son hoy difíciles de solventar. El primero se relaciona con los derechos humanos: la idea de un pueblo oprimido por una estructura social injusta, impedido de desarrollar libremente su personalidad, y que clama por sus libertades, que al fin han venido a ser reivindicadas en una carta de derechos. El segundo mito se vincula al régimen político: el pueblo ya no quiere tutores, pretende gobernarse a sí mismo, por lo que derrumba, en lucha democrática heroica, a los poderes de la monarquía absoluta impuestos "desde arriba" ${ }^{3}$.

Estos mitos se enfrentan con la realidad histórica de un pueblo que, en su generalidad, incluso en París, no protagonizó sino que "padeció" la Revolución ${ }^{4}$.

${ }^{1}$ Déclaration des droits de l Homme et du Citoyen. Texto original en el sitio del Conseil Constitutionnel (consultado el 25 de noviembre de 2015). Se identifica en bibliografía.

${ }^{2}$ Utilizamos el adjetivo "conservador" de un modo convencional para caracterizar, como hace Nisbet, el conjunto de teorías políticas que tienen como nota común el cuestionamiento de la Revolución Francesa, como filosofía, como movimiento histórico y como herencia política. NISBET, Robert, La formación del pensamiento sociológico (traducción de Enrique Molina, Buenos Aires, Amorrortu, 2009), I pp. 27-33. Genéticamente el cuestionamiento incluye a la Declaración de 1789 como base del "derecho nuevo" y del Estado moderno. Nisbet, Robert, Conservadurismo (Traducción de Diana Goldberg, Madrid, Alianza, 1986), p. 40. Gambra distingue entre conservadurismo y tradicionalismo: GAMBRA, Rafael, La monarquía social y representativa en el pensamiento tradicional (Madrid, Rialp, 1954), pp. 19-33. Compagnon habla de la corriente "conservadora" propiamente tal, la "reaccionaria" y la "reformista": Compagnon, Antoine, Los antimodernos (Traducción de Manuel Arranz, Barcelona, acantilado, 2008), pp. 33-40.

${ }^{3}$ Solé, Jacques, Historia y mito de la Revolución Francesa (México, Siglo Veintiuno, 1989), pp. 49-129. Más ampliamente, SuTHERLand, Donald, France 1789-1815: Revolution and Counter-Revolution (New York, Oxford University Press, 1985), pp. 15-87.

${ }^{4}$ Por todos, Cantero, Estanislao, La contaminación ideológica de la historia. Cuando los hechos no cuentan (Madrid, Libros Libres, 2009), p. 100, con gran acopio 
En la historia de las ideas políticas el hecho tiene su reflejo en la "Contra-Revolución”, corriente de reflexión política fundada en la tradición opuesta a la filosofía iluminista ${ }^{5}$. Es más, la Contra-Revolución, como resistencia activa y alzamiento en armas, fue un fenómeno de amplia base popular ${ }^{6}$. El Dictionnaire de l'Académie incorpora el término el año 1798. La "Contre-Révolution" pasa a ser definida como "segunda revolución en sentido contrario de la primera". El "contrarrevolucionario" es el "enemigo de la Revolución que trata de hacerla fracasar".

Por su parte, es incontestable que la Revolución instauró el sufragio igualitario, pero se legitimó con un reducido porcentaje de votos ${ }^{8}$. Furet afirma con ironía que "los hombres de 1789 amaron y proclamaron la

bibliográfico. Demográficamente las cifras son estremecedoras: seiscientos mil muertos en las guerras internas impulsadas por el ejército revolucionario, ciento diecisiete mil solo en el genocidio de la Vendée. Cuarenta mil ejecutados, de los cuales el 28\% son campesinos, $31 \%$ artesanos y obreros, $20 \%$ comerciantes, $8 \%$ nobles y $7 \%$ religiosos. Cuatrocientos mil muertos en las guerras exteriores mediante el sistema de reclutamiento masivo y forzado ("levée en masse"). Ciento cincuenta mil emigrados, de los cuales $25,2 \%$ del clero, $16,8 \%$ de la nobleza, $51 \%$ del estado llano y un $7 \%$ sin identificar. SEDIllot, René, Le cout de la Révolution Francaise (Paris, Perrin, 1987), pp. 12-54; Martin, Jean-Clément, La Vendée et la Révolution. Accepter la mémoire pour ecrire l'histoire (Paris, Perrin, 2007), pp. 50-88.

${ }^{5}$ Tulard, Jean (director), La Contre-Révolution. Origines, histoire, postérité (Paris, Perrin, 2013), especialmente pp. 15-424; MarTin, Jean-Clément (director), Dictionnaire de la Contre-Révolution, (Paris, Perrin, 2011), pp. 15-548. Más ampliamente, Martin, Jean-Clément, (director), La Contre-Révolution en Europe XVIIlèmeXIXème siècles (Rennes, PU, 2001), pássim ; y Veríssimo Serrao, Joaquín - Bullón DE MendozA, Alfonso (director), La Contra-Revolución legitimista (Madrid, Editorial Complutense, 1995), pp. 15-252. Para la cosmovisión contrarrevolucionaria, CoRRÊA De OliveIra, Plinio, Révolution et contre-révolution (Préface de S.A.I.R. le prince Dom Pedro Henrique de Orléans e Bragança, Paris, Éditions Catolicismo, 1960).

${ }^{6}$ Sobre el carácter popular de la Contra-Revolución, Совв, Richard, La protestation populaire en France (1789-1820) (Paris, Agora, 1989), passim; y LEBRUN, François - Dupuy, Roger (directores), Les Ressistances a la Revolution (Paris, Imago, 1987), passim.

${ }^{7}$ Citado por Gengembre, Gérard, La Contre-Révolution ou l'historie désespérante. Histoire des idées politiques (París, Imago, 1989), p. 21.

${ }^{8}$ Desde la primavera de 1791 , los ciudadanos empezaron a abandonar los asuntos públicos. En 1792 "el pueblo se fue a casa", dice Michelet. En las elecciones de la Convención (1792), con sufragio universal, en París votó menos del 10\%. En general, durante los años 1795-1799, sufragó menos del 20\% de los electores. GuENIFFEY, Patrice, "Elecciones", en Furet, Francois - Ozouf, Mona (editores), Diccionario crítico de la Revolución Francesa (traducción de Jesús Bravo y otros, Madrid, Alianza Editorial, 1989), pp. 49-60. El pueblo revolucionario, los "sans-culotte" eran reducidos en número. Совв, Richard, La protestation populaire, cit. (n. 6), p. 112; LeBRUN, François - DupuY, Roger, Les Ressistances a la Revolution, cit. (n. 6), pp. 180-190. 
libertad de todos los franceses, pero privaron a muchos de ellos del derecho a voto, y a otros del derecho a ser elegidos".

Compagnon observa que la idea de Contra-Revolución se desarrolló rápidamente porque la mayoría de sus argumentos habían sido elaborados antes de 1789 por los anti-iluministas ${ }^{10}$. Esta "contra-revolución", sea como movimiento histórico, sea en cuanto filosofía política, problematiza el significado simbólico de la Declaración de 1789, pues si ésta representa la conquista de una libertad nueva, no se comprende, de buenas a primeras, por qué un amplio sector del pueblo decide incluso morir por la libertad antigua ${ }^{11}$. La historiografía constitucional de corte liberal elude el problema silenciando la existencia de la "contra-revolución", o reduciendo su alcance a niveles nimios. Por su parte, se ha de observar que algunos de los maestros del pensamiento liberal hacen lo propio, llegando en ocasiones a tergiversar su caracterización ${ }^{12}$.

Hirschman clasifica en tres los modelos argumentales gatillados con ocasión de la Declaración de 1789: el principal, el argumento de "los efectos adversos" (la novedad revolucionaria produce efectos contrarios a los deseados), acompañado posteriormente por el de la "inanidad" (la revolución no cambia para bien con sus pretendidas mejoras) y por el del

${ }^{9}$ Furet, François, Le passé d une illusion (Paris, Laffont, 1995), p. 43.

${ }^{10}$ Compagnon, Antoine, cit. (n. 2), p. 29. Sobre el punto hay una amplia bibliografía. MASSEAU, Didier, Les Ennemis des philosophes. L'antiphilosophie au temps des Lumieres (Paris, Albin Michel, 2000); McMAHON, Darrin, Enemies of the Enlightenment. The French Counter-Enlightenment an the Making of Modernity (Oxford - New York, Oxford University Press, 2001); Goulemot, Jean-Marie, Adieu les philosophes. Que reste-t-il des Lumieres (Paris, Seuil, 2001), particularmente pp. 98-106.

${ }^{11}$ Sobre el alzamiento en el noroeste francés, es clásico SECHER, Reynald, Le Génocide Franco-Francais. La Vendée-Vengé (2a edición, Paris, PUF, 1988). También habría mucho que decir sobre la "ley de los sospechosos", que provocó quinientos mil detenidos y trescientos mil sometidos a arresto domiciliario. Y de las condenas por el tribunal revolucionario de París; el $71 \%$ de ellos pertenecía al estado llano. FORREST, Alan, La Révolution française et les pauvres (traducción del inglés por Marie-Alix Revellat, Paris, Perrin, 1986), p. 230; FAYARD, Jean Francois, La justice révolutionnaire. Chronique de la Terrour (Paris, Laffont, 1987), p. 268.

${ }^{12}$ Berlin, por ejemplo, coloca a De Maistre en la galería de los "enemigos de la libertad humana". Llega a sostener que es "el profeta de las fuerzas más violentas y más destructivas que han amenazado y que siguen amenazando la libertad y los ideales de los seres humanos normales". BERLIN, Isaiah, La traición de la libertad. Seis enemigos de la libertad humana (México, Fondo de Cultura Económica, 2004), p. 197. Sobre el saboyano, Gambra, Rafael, Joseph de Maistre y la idea de comunidad "Estudio preliminar", en De Maistre, Joseph, Consideraciones sobre Francia (Madrid, Rialp, 1955), pp. 9-59. 
"agravamiento" (el elevado costo de las medidas revolucionarias pone en peligro supuestos los beneficios adquiridos) ${ }^{13}$.

Los modelos argumentales precedentes requieren, en realidad, un telón de fondo. Lo da Compagnon cuando destaca una de las imputaciones más recurrentes contra la filosofía que encarna la Declaración de 1789: la Revolución es utópica e irrealista. Fundándose en premisas rousseaunianas simples y vulgares, considera a la sociedad como tabula rasa (De Maistre) o "carta blanca" (Burke). De ahí que en nombre de abstracciones -libertad e igualdad, soberanía del pueblo, voluntad general- pugne por imponer un estado de cosas, supuestamente perfecto, ignorando la experiencia, la historia, las costumbres y la ley natural ${ }^{14}$.

Esta imputación estuvo muy presente en los debates de la Asamblea. Se acusó de querer construir una sociedad nueva a partir de un plan preconcebido de espaldas a la realidad y a la propia historia. Maoluet imputa a la Declaración el volverse "metafísica", en el sentido de contraponerse a la realidad ${ }^{15}$. Necker en análogo sentido ${ }^{16}$. Es absurdo, exclama Lally-Tollendal, imponer un plano uniforme a un pueblo antiguo y diversos como Francia, que se ha dado una forma de gobierno hace más de 1400 años ${ }^{17}$.

Y es que en la mente de los revolucionarios, la Declaración era vista como el "código de la teoría revolucionaria"18, la filosofía de la nueva sociedad, que exigía ser fundada sobre los enunciados abstractos e ideales de libertad, igualdad, soberanía nacional y separación de poderes. No debía quedar "ninguna raíz viva del tronco constitucional" precedente, amenazaba Thouret $^{19}$. Es la razón pura la que debe hablar, agregaba Montmorency.

${ }^{13}$ Hirschman, Albert, Deux siecles de rhétorique réactionnaire (traducción de Pierre Andler, Paris, Fayard, 1991), pp. 91-92.

${ }^{14}$ Compagnon, Antoine, Los antimodernos, cit. (n. 2), p. 71.

${ }^{15}$ MaOluet, Pierre-Victor, "Discours du 1er août 1789" (Assemblée Nationale), en Archives numériques de la Révolution française, Archives Parlementaires (Edición on line), VIII, p. 323.

${ }^{16}$ NeCKER, Jacques, Du pouvoir exécutif dans les grands Etats, en Euvres complètes de M. Necker publiées par M. le Baron de Staël, (Paris, Treuttel et Wurtz, 1821), p. 310 .

${ }^{17}$ Lally-Tollendal, Trophime-Gérard, "Discours du 11 juillet 1789" (Assemblée Nationale), en Archives numériques de la Révolution française, Archives Parlementaires (Edición on line), VIII, pp. 222-223.

${ }^{18}$ Groethuysen, Bernard, Filosofía de la Revolución Francesa (México, Fondo de Cultura Económica, 1989), p. 210.

${ }^{19}$ Thouret, Jacques Guillaume, “Discour du 24 mars 1790” (Assemblée Nationale), en Archives numériques de la Révolution française, Archives Parlementaires, XII, p. 346. 
El poder (constituyente) construye desde cero, no tiene limitaciones, "no hay más que un solo poder", puntualizaba Sieyès ${ }^{20}$.

En contra, en los debates de la Asamblea Nacional una serie de diputados hace ver que la cuestión central para atribuir derechos no era el individuo abstracto en estado de naturaleza, sino la persona concreta en sus vínculos de sociedad. Para edificar una sociedad se requiere algo más que los derechos de sus miembros, agrega Grégorie ${ }^{21}$. De ahí que De Maistre apuntara al racionalismo político como el "error de principio" de la Revolución ${ }^{22}$.

\section{El SigNificado JURídico y Simbólico de la “DeClaracióN” DE 1789}

Es de notar que la Déclaration des droits de l'Homme et du Citoyen poseyó en su génesis más valor simbólico que jurídico. Apareció bajo las formas de unas nuevas tablas del Decálogo, para proyectarse con valor eterno ${ }^{23}$, como una suerte de "catecismo nacional" (Barnave) destinado a sacar al pueblo de su ignorancia.

La Declaración, sin embargo, fue un texto provisional. Pronto sufrió críticas decisivas que llevaron a refundirlo en dos ocasiones ${ }^{24}$. Tampoco tuvo soporte jurídico. No satisfizo a los diputados, por lo que nunca fue aprobado en las sesiones de la Asamblea Naciona ${ }^{25}$. Incorporada a la Constitución de $1791^{26}$, fue pronto sustituida. Primero por la Declaración de Derechos de la Constitución de $1793^{27}$, reemplazada a su vez por la Decla-

\footnotetext{
${ }^{20}$ Citado por Gauchet, Marcel, "Derechos del hombre”, en Furet, François Ozouf, Mona (editores), Diccionario crítico de la Revolución Francesa, cit (n. 6), p. 560.

${ }^{21}$ GaUChet, Marcel, "Derechos del hombre”, cit. (n. 20), p. 563.

${ }^{22}$ De Maistre, Joseph, Considérations sur la France, Inlibroveritas, edición on line, pp. 50-51.

${ }^{23}$ Tocqueville, Alexis de, L'Ancien régime et la Révolution, en El Mismo, Oeuvres completes (Paris, Gallimard, 1952), II, p. 89. Sobre el sentido de "pour tous les hommes et pour tous les temps", GAUCHET, Marcel, La Révolution des Droits de I Homme (Paris, Gallimard, 1989), pp. 136-143.

${ }^{24}$ Gauchet, Marcel, "Derechos del hombre”, cit. (n. 20), p. 558.

${ }^{25}$ Pichot-Bravard, Philippe, La Révolution Francaise (Versailles, Via Romana, 2014), p. 90

${ }^{26}$ Constitution DE 1791, 3 et 4 septembre 1791. Texto original en el sitio on line del Conseil Constitutionnel (consultado el 25 de noviembre de 2015). Se identifica en bibliografía.

${ }^{27}$ Constitution de l'An I, Première République, 24 juin 1793. Texto original en el sitio on line del Conseil Constitutionnel (consultado el 25 de noviembre de 2015). Se identifica en bibliografía.
} 
ración de Derechos y Deberes de la Constitución de $1795^{28}$. A esta le sucedió el título $1^{\circ}$ : "De l'exercice des droits de cité" de la Constitución de $1799^{29}$, suplido por la "Declaración de derechos" ("Droit public des Français") de la Carta de $1814^{30}$, relevada temporalmente por el título VI "Droits des citoyens" del Acte additonnel aux Constitutions de l'Empire de $1815^{31}$.

La Constitución de 1830 establece su propia declaración de derechos ("Droit public des Français") $3^{32}$, como lo hace en su capítulo $2^{\circ}$ ("Droits des citoyens") la Constitución de $1848^{33}$. No hay referencias formales a la Declaración de 1789 ni en la Carta de $1852^{34}$, ni en las leyes constitucionales de la III República ${ }^{35}$, ni en la del Gobierno provisorio de $1945^{36}$.

Es después de la Segunda Guerra Mundial que aparece formalmente, para efectos de su valor jurídico, la Declaración de 1789. La Constitución de 1946 recurre a ella en su preámbulo ${ }^{37}$, como lo hace también la Carta de $1958^{38}$.

${ }^{28}$ Constitution de l'An III, Directoire, 5 fructidor An III, 22 août 1795. Texto original en el sitio on line del Conseil Constitutionnel (consultado el 25 de noviembre de 2015).

${ }^{29}$ Constitution de l'An VIII, Consulat, 22 frimaire An VIII, 13 décembre 1799. Texto original en el sitio on line del Conseil Constitutionnel (consultado el 25 de noviembre de 2015). Se identifica en bibliografía.

${ }^{30}$ Charte de 1814,1 ire Restauration, 4 juin 1814 . Texto original en el sitio del Conseil Constitutionnel.

${ }^{31}$ Acte additionnel aux Constitutions de l'Empire, Cent-jours, 23 avril 1815. Texto original en el sitio on line del Conseil Constitutionnel (consultado el 25 de noviembre de 2015). Se identifica en bibliografía.

${ }^{32}$ Charte de 1830 , monarchie de Juillet, 14 août 1830 . Texto original en el sitio on line del Conseil Constitutionnel (consultado el 25 de noviembre de 2015). Se identifica en bibliografía.

${ }^{33}$ Constitution de $1848, \mathrm{II}^{\mathrm{e}}$ République, 4 novembre 1848 . Texto original en el sitio on line del Conseil Constitutionnel (consultado el 25 de noviembre de 2015). Se identifica en bibliografía.

${ }^{34}$ Constitution de 1852, Second Empire, 14 janvier 1852. Texto original en el sitio on line del Conseil Constitutionnel (consultado el 25 de noviembre de 2015). Se identifica en bibliografía.

${ }^{35}$ Lois constitutionnelles de 1875, III ${ }^{e}$ République, 24, 25 février et 16 juillet 1875. Texto original en el sitio on line del Conseil Constitutionnel (consultado el 25 de noviembre de 2015). Se identifica en bibliografía.

${ }^{36}$ Loi constitutionnelle du 2 nov. 1945, Gouvernement provisoire. Texto original en el sitio on line del Conseil Constitutionnel (consultado el 25 de noviembre de 2015). Se identifica en bibliografía.

${ }^{37}$ Constitution de 1946, IV ${ }^{\text {e }}$ République, 27 octobre 1946. Texto original en el sitio on line del Conseil Constitutionnel consultado el 25 de noviembre de 2015). Se identifica en bibliografía.

${ }^{38}$ Constitution de $1958, V^{e}$ République, 4 octobre 1958 . Texto original en el sitio 
El valor simbólico de la Declaración de 1789 es conocido ${ }^{39}$. A veces nos encontramos incluso con una auténtica mitificación ${ }^{40}$. Este cariz simbólico, o en su caso mítico, se encuentra ampliamente registrado en la historia de las ideas políticas y se puede rastrear ya en la misma época en que fue generado el documento ${ }^{41}$.

Para Michelet, la Revolución Francesa, cristalizada en sus inicios por la Declaración de 1789, fue "el advenimiento de la ley, la resurrección del derecho, la reacción de la justicia" ${ }^{2}$. "El pensamiento grande, agrega, verdaderamente santo de la Revolución es la liberación del mundo" ${ }^{43}$. Nos encontramos ante la revolución de la libertad, de la igualdad y de los derechos humanos, proclama Soboul in extenso ${ }^{44}$.

Para Robespierre, la Declaración es la base ideológica de la Revolución Francesa, "la primera revolución fundada sobre los derechos humanos" 45 . Paine vincula la Declaración a la "regeneración del hombre" 46 . Kant, sa-

on line del Conseil Constitutionnel (consultado el 25 de noviembre de 2015). Se identifica en bibliografía.

${ }^{39}$ Por todos, Gauchet destaca que la Declaración representa la "cristalización de una lógica política destinada a pesar sobre el curso entero de la Revolución”, así como "la instalación de una libertad e igualdad individuales" en un "rol inaugural y seminal, pero decisivo": GAUCHET, Marcel, La révolution des droits de l'homme, cit. (n. 23), p. iv.

${ }^{40}$ Véase, por ejemplo, el trato de aurora de la nueva era que le da BobBIo, Norberto en El tiempo de los derechos (traducción de Agustín de Asís, Madrid, Sistema, 1991), p. 132; o el de Hunt, Lynn en Inventing Human Rights: A History (New York, Norton Company, 2007), pp. 146-175, junto a las otras declaraciones simbólicas de la Modernidad.

${ }^{41}$ La evocación apologética de la Declaración hace parte de la mitología revolucionaria que la historiografía oficial francesa (Jaures, Aulard, Lefebvre, Mathiez, Soboul, Vovelle) ha difundido sobre todo a partir de la III República, en la estela de Jules Michelet. Al extremo de que, según Cantero, la Gran Revolución es uno de los acontecimientos "peor conocidos por el público". CANTERO, Estanislao, La contaminación ideológica de la historia, cit. (n. 4), p. 96. Una aguda crítica a la historiografía oficial de la Revolución, en FURET, François, Historia universitaria de la Revolución Francesa, en Furet, François - Ozouf, Mona (editores), Diccionario crítico de la Revolución Francesa, cit (n. 6), pp. 798-813; y BelLoIN, Gerard, Entendez-vous dans nos memoires? Les Français et leur Revolution (Paris, La Decouverte, 1988), passim.

${ }^{42}$ Michelet, Jules, Historia de la Revolución Francesa (Buenos Aires, Argonauta, 1946), I, p. 7.

${ }^{43}$ Ibíd., III, p. 74.

${ }^{44}$ Soboul, Albert, La Revolución Francesa. Principios ideológicos y protagonistas colectivos (Barcelona, Crítica, 1989), pp. 91-136.

${ }^{45}$ Robespierre, Maximilien, Oeuvres complètes (Paris, Société des Études Robespierristes, 1967), X, p. 544.

${ }^{46}$ Paine, Thomas, Derechos del hombre (Madrid, Alianza Editorial, 1984). 
liendo de su parquedad habitual, agrega que ella, junto a la Revolución que inicia, es una prueba de la "disposición moral" del género humano hacia el progreso, que debe ser recibida con una "simpatía rayana en el entusiasmo" ${ }^{47}$. Para Hegel, en fin, la Declaración representa la "espléndida aurora", el "entusiasmo del espíritu" ("Enthusiasmus des Geistes") por el que se realiza el "principio de libertad"48.

Empero, Pichot-Bravard ha recordado recientemente que la terminología "derechos del hombre" no fue un invento de los diputados de la Asamblea Nacional. Es también utilizado en el antiguo régimen como señal de garantía jurídica. Es invocado, por ejemplo, por diversas autoridades políticas del reinado de Luis XV (vr. gr. Turgot, Lamoignon de Malesherbes, Moreau), por el Parlamento de París y por el mismo Luis XVI ${ }^{49}$.

¿Qué representa, entonces, la Declaración de 1789? ¿Por qué Del Vecchio sostiene que realiza un nuevo derecho radicalmente diferente del antiguo? ${ }^{50}$

Aproximándose a la común perspectiva constitucional, muchos han sostenido, siguiendo a Roselli, que la Declaración encarna el "triunfo del principio de libertad" 51 . Particularmente de la libertad civil, política y económica.

Bobbio señala que, a nivel simbólico-político, la Declaración proclama la libertad, la igualdad y la soberanía popular ${ }^{52}$. En un análisis jurídico, recalca que el núcleo doctrinal de la Declaración de 1789 se expresa en tres ideas: la condición natural de los individuos que precede a la formación de la sociedad civil, y de la cual derivan derechos y libertades inalienables; el contrato social como fundamento de una sociedad que se ha de organizar para preservar dichos derechos; y el principio de legitimidad de la representación una e indivisible de la soberanía nacional, base de todo gobierno democrático futuro ${ }^{53}$.

Ferrajoli destaca la Declaración de 1789 como un cambio de paradig-

${ }^{47}$ KanT, Immanuel, Replanteamiento sobre la cuestión de si el género humano se halla en continuo progreso hacia lo mejor, en EL Mismo, Ideas para una historia universal en clave cosmopolita y otros escritos sobre filosofía de la historia (Traducción de Concha Roldán, 2a edición, Madrid, Tecnos, 1994) p. 83.

${ }^{48}$ Hegel, Georg Wilhelm Friedrich, Filosofia da história (Traducción de María Rodrigues y Hans Harden, Brasilia, Editora UNB, 1995), p. 364.

${ }^{49}$ Pichot-Bravard, Philippe, La Révolution Francaise, cit (n. 25), pp. 88-90.

${ }^{50}$ Del Vecchio, Giorgio, La declaración de los derechos del hombre y del ciudadano en la Revolución Francesa, en El Mismo, Persona, Estado y derecho (Madrid, Instituto de Estudios Políticos, 1957), p. 49.

${ }^{51}$ Rosselli, Carlo, Socialismo libérale (Torino, Einaudi, 1979), pág. 90.

${ }^{52}$ Boвbio, Norberto, cit. (n. 40), pp. 132.

${ }^{53}$ Ibíd., pp. 140-141. 
ma sobre el que se desarrolla el constitucionalismo contemporáneo. El reconocimiento de los derechos fundamentales, la división de poderes y el principio de legalidad son ideas matrices que, incluso después de dos siglos, permiten redescubrir el valor de la Constitución "como límite y vínculo a los poderes públicos" $"$.

Tienen parte de verdad las conocidas acusaciones de Marx contra la Declaración $^{55}$, renovadas por Marshall, en el sentido de que consagraría solo los derechos que son esenciales para el desarrollo del primer capitalismo ${ }^{56}$. Pero al sentimiento de libertad debe sumarse la idea de igualdad, como indica Ruggiero. De la Declaración brota una nueva interpretación de los conceptos de libertad e igualdad, en un intento de ajuste entre las aspiraciones liberales y las demócratas. En esta línea, "los principios inmortales" del 89, con su difícil encuadre entre las reivindicaciones de las libertad naturales y la indivisibilidad de la soberanía estatal, serán el punto de partida para "la revolución liberal, la revolución democrática y la revolución social" 57 .

Vista la Declaración desde un horizonte retrospectivo, se trata, como afirma Gauchet, del despliegue de una manera "matricial" de plantear el problema de los derechos del hombre. Hay una unidad intelectual del proceso revolucionario que cristaliza inauguralmente en la Declaración. Los "derechos del hombre" son "una pieza eminente del dispositivo", primero en su faceta liberal, después en su dimensión estatal-igualitaria. De ahí que la Declaración de Independencia de los Estados Unidos sirva para eludir el ejemplo de la constitución inglesa y "su sedimentación "gótica", evitando volver al modo antiguo de reconocer y garantizar los derechos ${ }^{58}$.

El modo antiguo expresa una historia previa, que se hace preciso borrar. La Declaración deviene, entonces, en "máquina de guerra” contra el Antiguo Régimen ${ }^{59}$. Para su simbología, apunta Zagrebelsky, las libertades y derechos históricos no son más que el "cúmulo de la causalidad irracional" que ha de ceder el campo de lo político y lo jurídico al voluntarismo de

${ }^{54}$ Ferrajoli, Luigi, Derechos y garantías. La ley del más débil (Traducción de Perfecto Andrés Ibánez, Madrid, Trotta, 2010), pp. 67 y 138.

${ }^{55}$ MarX, Karl, La cuestión judia, en El Mismo, Anales franco-alemanes (Barcelona, Martínez Roca, 1970), p. 243. En referencia a la libertad del hombre como mónada aislada, Ibid. p. 243.

${ }^{56}$ Marshall, Citizenship and Social Class: And Other Essays (Cambridge, Cambridge University Press, 1950), pp. 92-96.

${ }^{57}$ Ruggiero, Guido de, Historia del liberalismo europeo (Traducción de Carlos G. Posada, Granada, Comares, 2005), pp. 68-71.

${ }^{58}$ Gauchet, Marcel, Derechos del hombre, cit. (n. 20), p. 558.

${ }^{59}$ Tulard Jean y otros, Historia y Diccionario de la Revolución Francesa, cit. (n. 41), p. 58. 
una humanidad iluminada. En esta dinámica, la Declaración supone una "concepción anti-histórica", que busca la inmutabilidad absoluta de una nueva y eterna constitución, considerada como hija de la Razón ${ }^{60}$.

\section{La lectura conservadora de la “Declaración” de 1789.}

\section{LA CONTESTACIÓN AL DISCURSO MODERNO DE LOS DERECHOS HUMANOS}

Si se tiene en cuenta que los derechos consagrados en la Declaración se recogen en prácticamente todas las constituciones democráticas del mundo actual, ¿a qué título un conjunto de teorías políticas que llamamos "conservadoras" podría hoy razonablemente cuestionarlos? ¿Cuál es el sentido de dicho cuestionamiento?

El punto de entrada de la lectura conservadora es el análisis del lenguaje aparentemente neutro de los derechos humanos, expresados en fórmulas abstractas y universales, como lo hace la Declaración de 1789. La imputación que los conservadores han hecho al documento, según veremos, es fundante: la neutralidad de los derechos atribuidos a todos los hombres no es tal. Primero, porque el idealismo abstracto en la enunciación de los derechos universales no es fruto de una determinación jurídica sino de una metodología acorde con un programa político determinado. Segundo, dicha neutralidad debe ser leída desde los parámetros antropológicos y a-religiosos de dicho programa político anclado exclusivamente en la cultura iluminista. La conclusión se impone: los derechos enunciados en abstracto adquieren en concreto un carácter inmediatamente instrumental para la construcción de la sociedad revolucionaria a partir del nuevo tipo de hombre imaginado por el iluminismo.

Absurdos como considerar la sociedad cual máquina, o a las personas como individuos a-sociales y universales, se han aceptado casi por inercia intelectual $^{61}$. Estas concepciones que inspiran la Declaración de 1789 suponen una verdadera "invención del hombre", esta vez en el sentido peyorativo del término. A continuación, un análisis de sus estructuras ideológicas.

${ }^{60}$ ZagrebelsKy, Gustavo, Historia y constitución (Traducción de Miguel Carbonell, Madrid, Trotta, 2005), pp. 35 y 40.

${ }^{61}$ "Jamais on ne comprendra le mécanisme social, si lon ne prend pas le parti d'analyser une société comme une machine ordinaire", escribe SIEYES, Emmanuel-Joseph, Qu'est-ce que le Tiers-état? (Paris, Flammarion, 1988), p. 123. Por el contrario, Luis XIV anota: "Car enfin, mon fils, nous devons considérer le bien de nos sujets bien plus que le nôtre propre. Il semble qu' ils fassent une partie de nous-mêmes, puisque nous sommes la tête d' un corps dont ils sont les membres" : citado por SoleIL, Xavier, en "Les 4 vérités hebdo", n. 958, vendredi 5 septembre 2014. 


\section{Una visión global de la "Declaración": la ideología de la libertad e igualdad.}

La Declaración representa la nueva ideología de la "libertad" y la "igualdad" ${ }^{2}$. La cultura que genera e interpreta este discurso de los derechos humanos viene pre-determinada por el racionalismo y el secularismo político, y dentro de esos marcos hay que comprenderlo. En este sentido, la Declaración no tiene como objeto fundamental, como hoy se cree, proclamar los derechos naturales del hombre, a fin de proscribir para siempre la arbitrariedad política y el abuso jurídico. Va mucho más allá del discernimiento de las contingencias históricas de la extensión del poder político y de su deseo de limitarlo ${ }^{63}$. Ella tiene como meta fundamental insertar simbólicamente en el dinamismo de los hechos históricos una nueva ideología politica, articulada sobre el principio abstracto de la libertad e igualdad revolucionarias, consciente de que con ello se violan los derechos y libertades concretas del orden vigente.

Se puede formular una panorámica general del articulado de la Declaración en este sentido. El racionalismo y el secularismo político quedan bien plasmados en el preámbulo de la Declaración ${ }^{64}$. El respeto por los derechos del hombre, configurados en abstracto, acarreará, se dice, la felicidad de los pueblos. El Estado emergente se hará cargo de que el nuevo orden político gire en torno a estos derechos, bajo la presencia del Ser Supremo, denominación deísta-masónica que reemplaza a Jesucristo, a Quien estaba consagrada la monarquía francesa, y a Quien hasta el momento veneraba el pueblo francés. Los revolucionarios se arrogan una especie de papel sacerdotal laico mediante el cual pretenden ilustrar los nuevos dogmas políticos de la Modernidad como si fueran la nueva encarnación de lo sagrado ${ }^{65}$.

${ }^{62}$ Sobre la génesis histórico-conceptual de la ideología de la igualdad y la libertad, Gauchet, Marcel, La Révolution des Droits de l'Homme, cit. (n. 23), pp. 7-201 (revolución de la libertad) y pp. 203-316 (revolución de la igualdad). También Rials Stéphane, La Déclaration des droits de l'homme et du citoyen (Paris, Hachette, 1989), pp. 35-546.

${ }^{63}$ En principio, el poder político estaba mucho más limitado en el Ancien régime que en la democracia estatal moderna. En la Francia pre-revolucionaria, el poder central del rey, que en teoría podía ser "absoluto" frente a otros poderes temporales, estaba sujeto a muchísimos límites y contrapesos provenientes de su constitución histórica. Este es un punto eludido por el constitucionalismo liberal. Sobre la materia, BASSE, Bernard, La constitution de l ancienne France. Principes et lois fondamentales de la Royaute Francaise (Paris, Les Presses Saint Louis, 1973); y Deswarte, Marie-Pauline, La République organique en France (Versailles, Via Romana, 2014).

${ }^{64}$ Déclaration des droits de P Homme et du Citoyen, cit. (n. 1).

${ }^{65} \mathrm{La}$ Asamblea Nacional declaró en agosto de 1791 el "carácter religioso y sagrado" de la Declaración. Es la "nueva fe política” según GAUCHET, Marcel, La Révolu- 
La libertad y la igualdad abstractas, consecuencia de aquel racionalismo y secularismo, se consagran como valores caros a la Revolución en el artículo primero $^{66}$. Su función es polémica: están destinados a repudiar el peso de la tradición, de la historia y de la misma naturaleza en la diferenciación humana, reflejada jurídicamente en la sociedad estamental y en el tejido de libertades familiares y asociativas ${ }^{67}$.

La lógica de la igualdad es atenazada en la Declaración por dos dinamismos contrapuestos: el igualitarismo filo-comunista que eclosiona con Babeauf y la igualdad puramente jurídica y formal de la sociedad liberal burguesa, en cuyo marco se desenvolverá a futuro la nueva propiedad individual $^{68}$.

El artículo segundo ${ }^{69}$ nos muestra una de las premisas claves del liberalismo: toda la sociedad política, que ahora se construye ex novo, gira en torno a la satisfacción de los derechos y libertades individuales. La opresión es todo aquello que no nace de la voluntad general, que opera el único paso legítimo entre el estado de naturaleza y el estado social.

El artículo tercero ${ }^{70}$ consagra el dogma de la soberanía popular a través del concepto de nación, que al constituir un concepto puramente abstracto y a-histórico, permite a los revolucionarios invocar la representación de la voluntad soberana, incluso contra los deseos de gran parte de la población ${ }^{71}$.

El artículo cuarto proclama la libertad negativa ${ }^{72}$, desligada de toda

tion des Droits de l'Homme, cit. (n. 23), p. 9. Voegelin ve la incidencia gnóstica, particularmente en el ensayo de cambiar la naturaleza humana y establecer la sociedad transfigurada: Voegelin, Eric, La nueva ciencia de la política (Traducción de Joaquín Ibarburu, Buenos Aires, Katz, 2006), pp. 225 y 184.

${ }^{66}$ Artículo 1: "Les hommes naissent et demeurent libres et égaux en droits. Les distinctions sociales ne peuvent être fondées que sur l utilité commune".

${ }^{67}$ Sobre el peso revolucionario del artículo 1: GAUCHET, Marcel, La Révolution des Droits de l'Homme, cit. (n. 23), pp. 28-35 y 37-48. Su carácter radical: Ріснот, Philippe, La Révolution Francaise, cit (n. 25), pp. 92.

${ }^{68} \mathrm{La}$ tensión entre la revolución de la igualdad y la revolución de la propiedad individual y burguesa, Gauchet, Marcel, La Révolution des Droits de l'Homme, cit. (n. 23), pp. 209-256. El artículo 17 de la Declaración establece el derecho de propiedad individual, que en su aplicación liberal será un cernedor del derecho de propiedad familiar y comunal.

${ }^{69}$ Artículo 2: "Le but de toute association politique est la conservation des droits naturels et imprescriptibles de l Homme. Ces droits sont la liberté, la propriété, la sûreté, et la résistance à loppression”.

${ }^{70}$ Artículo 3: "Le principe de toute Souveraineté réside essentiellement dans la Nation. Nul corps, nul individu ne peut exercer dautorité qui n'en émane expressément".

${ }^{71}$ Sobre la resistencia de "uno" frente al irresistible "poder de todos": GAUCHET, Marcel, La Révolution des Droits de l'Homme, cit. (n. 23), pp. 150-157.

${ }^{72}$ Libertad negativa, entiéndase bien, en un sentido antropológico y no jurídico, 
norma o principio trascendente, como principio político revolucionario: "la liberté coiste à pouvoir faire tout ce qui ne nuit pas à autrui". Y como no hay nada que pueda limitar esa libertad -ya no se reconoce la ley divinonatural, ni el derecho consuetudinario, ni las leyes históricas fundamentales del Reino- es el Estado el que ahora se arroga el poder omnímodo de señalar los límites a través de la ley: "ces bornes ne peuvent être déterminées que par la Loi”. La libertad negativa sirve de base para la instauración del poder soberano estatal.

El artículo sexto confirma la orientación estatista de los artículos 3 y 4 in fine a través de la categoría de la voluntad general, así como la ideología igualitaria que impregna el documento.

Los artículos 10 y 11 recogen respectivamente la libertad de religión y la libertad de pensamiento, e implícitamente, la libertad de conciencia, pues ambas no son más que instancias de ésta, cuya esencia puede considerarse anclada en la noción de libertad negativa del artículo 4 . El artículo 10 reduce la religión a una opinión y la subordina a los fines del Estado, dado que puede ser limitada en razón del orden público ${ }^{73}$. La libertad de pensamiento es considerada como uno de los derechos más preciosos del Hombre ("des droits les plus précieux de l'Homme"), porque permite criticar los dogmas cristianos y la moral social de la Francia entonces católica. Tal libertad no puede dirigirse, sin embargo, contra los bienes fundamentales del nuevo orden político, por lo que quienes abusen de ella deben responder ante la ley ${ }^{74}$.

En la Declaración francesa de 1789 ya se dejan ver los dos pilares sobre los que se levanta el discurso emancipatorio de los derechos humanos, y que en las sucesivas declaraciones -especialmente las del siglo XX-se explicitarán de una forma cada vez más clara: i) Una conciencia moral desvinculada de la ley divino-natural y de toda norma trascendente; y ii) Una noción débil de religión, que posteriormente incluirá la irreligión, bajo el rótulo de "creencia”. Se parte de la inexistencia o incognoscibilidad social de una Revelación religiosa magisterial, como la cristiana. Y de la reducción de la fe a una mera opinión subjetiva. Volveremos a continuación sobre el problema.

puesto que jurídicamente se expresa en derechos negativos (no ser forzado a) y afirmativos (derecho a actuar).

${ }^{73}$ Gauchet, Marcel, La Révolution des Droits de l'Homme, cit. (n. 23), pp. 167174.

${ }^{74}$ Sobre la tensión entre los derechos de los ciudadanos y los derechos de la nación, y la subsecuente subordinación de los primeros a los segundos: GAUCHET, Marcel, La Révolution des Droits de l'Homme, cit. (n. 23), pp. 174-183. 


\section{Secularismo y racionalismo politico.}

El secularismo y el racionalismo político como principios de la Declaración han sido destacados recientemente por Pichot-Bravard. Encarnan una triple voluntad revolucionaria:

a) La "voluntad de secularización" de la sociedad, que coloca al hombre en el lugar que en el cosmos le corresponde a Dios. De ahí que la Declaración sea redactada bajo los auspicios del Ser Supremo, el gran arquitecto de los deístas, al que se le asigna un rol únicamente inspirador en las cosas de este mundo. La sociedad queda totalmente en manos de los hombres. El gran arquitecto, de los círculos iluministas, sustituye al Dios trinitario de la inmensa mayoría de los franceses.

b) La "voluntad de racionalizar" la sociedad exige la destrucción o eliminación de todos los elementos "irracionales", de todo aquello que no cabe en un enunciado uniforme. De ahí la exigencia de eliminación o destrucción de los cuerpos intermedios, las corporaciones, las libertades particulares y las tradiciones, osadura del Antiguo Régimen. Es la política de la "tabla rasa" 75 .

Pichot-Bravard destaca que a diferencia de la revolución inglesa, la Gran Revolución descarta toda idea de restauración de las libertades tradicionales. Los llamados de Cazales y Montlosier para restaurar la monarquía temperada, consultiva y descentralizada son ahogados. El racionalismo pide que el hombre revolucionario disponga de todas las cosas: la sociedad hay que reconstruirla desde cero sobre los fundamentos abstractos consagrados en la Declaración.

Subsecuencia de la voluntad de racionalizar es la "voluntad de universalidad". Todo aquello que podría enraizar la Declaración en la realidad francesa ha sido escamoteado. De ahí la eliminación consecuencial de todos los elementos diferenciadores de la realidad francesa: desde las denominaciones territoriales (desaparecen los países y regiones sustituidos por departamentos) hasta el Calendrier républicain (supresión del calendario gregoriano, eliminación de las fiestas religiosas y los feriados locales) ${ }^{76}$.

${ }^{75} \mathrm{El}$ secularismo no es separable del racionalismo político. El modelo de mundo perfecto pretendido por el racionalismo rechaza el orden natural "imperfecto" creado por Dios. En otros términos, el designio de construir un gobierno exclusivo de los hombres sobre la tierra ha de ser independiente de todo vínculo trascendente. El orden "natural" (y divino) debe ser reemplazado por el orden "racional": Grasso, Pietro Giuseppe, El problema del Constitucionalismo, cit. (n. 63), p. 84; CASTELlano, Danilo, Racionalismo y derechos humanos. Sobre la anti-filosofía politico-jurídica de la “modernidad" (Traducción de Coral García, Madrid, Marcial Pons, 2004), pp. 23 y 24.

${ }^{76}$ Pichot-Bravard, Philippe, La Révolution Francaise, cit. (n. 25), pp. 85-95. 
Se puede observar en la historia del pensamiento político conservador el desarrollo y profundización de estas vetas:

a) La advertencia sobre la secularización y sus peligros para la política moderna es iniciada por De Maistre quien postula el carácter "satánico" de la Revolución, revelada en su faceta anti-cristiana, sea por vía directa (el ensayo de eliminación del catolicismo y de sus símbolos), sea por vía indirecta (la demolición del orden social pre-revolucionario y del "orden natural") ${ }^{77}$. Desenvuelven esta línea Pierre Cloriviere, Donoso Cortés, el Cardenal Louis Pie, Henri Delassus y Louis Billot, entre muchos otros, hasta llegar a Correa de Oliveira, quien, doscientos años después, vuelve a recordar el carácter "satánico" de la Revolución" ${ }^{78}$. La obra anticristiana de la Revolución no es una mera incidencia o un cúmulo explosivo de pasiones no controladas, sino una sistemática de ideas, pasiones y acciones enraizadas en una lógica profunda ${ }^{79}$.

En este contexto, la Declaración de 1789 es leída como el catecismo laico que expresa esa "teofobia" hacia el Dios cristiano ${ }^{80}$. La Declaración representaría un giro metafísico en la política: la soberanía de Dios es re-

${ }^{77}$ De MaIstre, Joseph, Considérations sur la France, cit. (n. 22), pp. 29-45, donde formula las célebres palabras : "Ily a dans la révolution française un caractère satanique qui la distingue de tout ce qu'on a vu, et peut-être de tout ce qu'on verra".

${ }^{78}$ El filósofo insiste en muchos textos. Refiere a "a hidra satânica da Revolução", al "espírito satânico com que demoliram o Trono e pretenderam destruir o Altar", reivindicando expresamente la mirada de teología política en este ámbito. CORRÊA DE Oliveira, Plinio, O centro do mundo, en Legionário, 490 (1 de fevereiro de 1942), edición on line; El Mismo, A Nota da Semana, en O Século, 17 de julho de 1932, edición on line; El Mismo, Nobleza y elites tradionales análogas em las alocuciones de Pio XII al patriciado y a la nobleza romana (2a edición, Madrid, Fernando III, 1995), pp. 229 y 231.

${ }^{79} \mathrm{La}$ tesis de una Revolución esencialmente anti-cristiana, incluso de carácter conspirativo para arrumbar la Cristiandad, ha sido desarrollada por múltiples autores bajo la impronta dejada por Augustin Barruel: François Lefranc, Francesco Gusta, Jacques Crétineau-Joly, Nicolás Deschamps, Claude Francois Beaulieu. En las últimas décadas, con gran erudición: DuMONT, Jean, La Révolution française ou les prodigues du sacrilège (Limoges, Criterion, 1988), pp. 188-335; y VigUeRIE, Jean, Christianisme et révolution: cinq leçons d' histoire de la Révolution Française (París, NEL, 2000). Los efectos jurídicos en Alvear Téllez, Julio, La Revolución Francesa: el legado de descristianización y violación de los derechos fundamentales, en AA. VV., Revisión del legado jurídico de la Revolución Francesa en las Américas (Santiago, Ediciones Universidad Bernardo O'Higgins, 2013), pp. 255-287.

${ }^{80}$ Sobre la "teofobia" como ímpetu espiritual que caracteriza la filosofía iluminista, particularmente en el ámbito temporal y político, es clásico el texto de DE Maistre, Joseph, Las veladas de San Petersburgo (Buenos Aires, Espasa-Calpe, 1943), pp. $120-121$. 
emplazada por la soberanía del pueblo, por la voluntad general ${ }^{81}$. En este cuadro prometeico es donde se plasma efectivamente el "alejamiento de lo divino" en la sociedad temporal, alimentando de un modo definitivo la reconstrucción de un orden jurídico y político sin Dios como referencia de los deberes sociales y políticos primarios ${ }^{82}$.

b) La denuncia del racionalismo político como filosofía inspiradora de la Declaración de 1789 es manifestada en sus primeros momentos por De Maistre y De Bonald en Francia, por Burke en Inglaterra y por Rodríguez Campomares en España, con gran efectividad política, como puede deducirse del célebre "Manifiesto de los Persas" contra la Constitución de Cádiz. Con diversos matices, se destaca que el racionalismo político es esencialmente destructivo en cuanto ajeno a la experiencia, a la naturaleza social del hombre, al sentido de comunidad, a la herencia y al localismo de la vida, de la tierra y de la patria ${ }^{83}$. A la radicalidad aniquiladora de Saint-Etienne ${ }^{84}$ o de Sieyès ${ }^{85}$ puede oponerse, como término comparati-

${ }^{81}$ Clement, Marcel, Réflexions sur la Révolution, en Esquier, Genevieve, Une histoire chrétienne de la Révolution Française (Paris, Escalade, 1989), pp. 9-11.

${ }^{82}$ Gauchet lo formula con agudeza: "Es en el cuadro de este distanciamiento general de Dios, de su criatura y de su mundo que se opera la transferencia conceptual decisiva del derecho de Dios al dominio creado por el hombre, quien se reconoce por nacimiento y por esencia con el derecho de apropiarse de todas las cosas. El hombre de los derechos del hombre surge de la secesión divina, que le deja en su soledad de origen ante un universo vacante donde libremente desarrollar sus poderes". GAUCHET, Marcel, La Révolution des Droits de l'Homme, cit. (n. 23), pp. 16-17.

${ }^{83} \mathrm{La}$ agudeza e ironía son notables a la hora de expresar estas ideas. Por ejemplo, De Maistre, Joseph, Sobre la soberanía popular. El anti-contrato social (Madrid, Mayo Editores, 2014), p. 51 y 61; BURKE, Edmund, Reflexiones sobre la Revolución Francesa (Madrid, Alianza, 2013), pp. 72 y 157

84 "Pour rendre le peuple heureux, il faut le renouveler, changer ses idées, changer ses lois, changer ses moeurs, changer les hommes, changer les choses, changer les mots [...]. Tout détruire; oui tout détruire puisque tout est à récréer" : SAINT-ETIENNE, Rabaud, Discours du 11 novembre 1789, Assemblée Nationale, en El Mismo, Discours et opinions de Rabaut-Saint-Etienne, suivis de ses deux derniers écrits (Paris, Henri Servier, 1827), p. 118

${ }^{85}$ "La nation existe avant tout, elle est l'origine de tout. Sa volonté est toujours légale, elle est la loi elle-mesme": SIEYES, Emmanuel-Joseph, Qu'est-ce que le Tiers-état? cit (n. 86), p. 127. 
vo, la lúcida mofa de Rivarol ${ }^{86}$ y el "aterrador espectáculo" revisitado por Tocqueville ${ }^{87}$.

En la apreciación conservadora, el racionalismo político elimina o succiona la tradición vital, las libertades asociativas y la prudencia política. La nueva sociedad la construye sobre dos ejes variables: en la base, el individualismo abstracto, en la cima el Estado revolucionario. La cadena que los une es la soberanía nacional y contractualista expresada en la voluntad general.

Sin esta filosofía no es posible comprender la Declaración de $1789^{88}$. Hay que añadir además el tono singular en que ambas son expresadas. En los labios del "parti philosophique" todo suena más radical de lo que hoy estamos acostumbrados. Herederos de la secularización protestante, de los "esprits forts" del Grand Siècle, cultivan la libertad como emancipación, el principio de subjetividad, el odio a Roma (al Papado), y el rompimiento material o formal con el cristianismo en cuanto norma de vida política y social ${ }^{89}$. Son las teclas con las que se toca acertadamente la música revolucionaria de la Declaración, y con la que se puede discriminar a los hombres ${ }^{90}$.

${ }^{86}$ Rivarol evidencia hasta el ridículo el "mos geometricus" de las nuevas declaraciones y cartas constitucionales: "Article premier. A compter du 14 juillet prochain, les jours seront égaux aux nuits pour toute la surface ... Au moment où le jour finira, la lune commencera à luire, et elle sera dans son plein ... d'une extrémité à lautre du globe une température modérée et toujours égale" : Rivarol, Antoine de, Collection des mémoires relatifs a la Révolution Francaise. Mémoires de Rivarol, avec des notes et éclaircissements historiques (Paris, Badouin, 1824), p. p. 353.

87 "Quand on étudie l histoire de notre révolution, on voit qu'elle a été menée précisément dans le même esprit qui a fait écrire tant de livres abstraits sur le gouvernement. Même attrait pour les théories générales, les systèmes complets de législation et lexacte symétrie dans les lois; même mépris des faits existants; même confiance dans la théorie; même goût de loriginal, de lingénieux et du nouveau dans les institutions; même envie de refaire à la fois la constitution tout entière suivant les règles de la logique et d’ après un plan unique, au lieu de chercher à lamender dans ses parties. Effrayant spectacle! Car ce qui est qualité dans l écrivain est parfois vice dans l homme d État, et les mêmes choses qui souvent ont fait faire de beaux livres peuvent mener à de grandes révolutions": TOCQUEVILLE, Alexis de, L'Ancien régime et la Révolution (Paris, Flammarion, 1988), p. 238.

${ }^{88}$ Para explicitar esta filosofía desde el ángulo histórico conceptual, de especial relevancia son las investigaciones que se fundan en los proyectos y debates que dieron origen a la Declaración de 1789. De la bibliografía francesa contemporánea hay que destacar: Baecque, Antoine de - Schmale, Wolfgang - Vovelle, Michel, L'An I des droits de l'homme (París, CNRS, 1988) y las obras ya citadas de Rials y Gauchet.

${ }^{89}$ Es clásico Fabre, Joseph, Les Péres de la Révolution. De Bayle a Condorcet (Alcan, París, 1916). Más actual, Viguerie, Jean de, Histoire et Dictionnaire du temps des Lumières (Paris, Laffont, 1995), pp. 268-275.

${ }^{90}$ Los "philosophes" acostumbraban a categorizar a los hombres entre aquellos que merecen ser sujetos de derechos y aquellos que aún no han alcanzado la mayoría 
Vistas las cosas de manera más particularizada, esta filosofía opera una amplia modificación en el campo de lo que hoy denominamos derechos fundamentales. Lo que puede visualizarse de distintas maneras:

a) El uso revolucionario de los derechos subjetivos. Los derechos contenidos en la Declaración suponen, en primer lugar, un nuevo lenguaje: el de los discursos ampulosos y abstractos, desvinculados de cualquier lazo de justicia concreta y de circunstancias históricas vitales y determinantes. Son los derechos del "estado de naturaleza" que se positivizan pensando en hombres a-históricos y genéricos. De ahí las poderosas imágenes críticas de De Maistre ${ }^{91}$, Burke ${ }^{92}$, o más cercanamente Villey ${ }^{93}$.

El uso revolucionario de los derechos del hombre se manifiesta asimismo en el individualismo y el contractualismo, dos ejes ideológicos del racionalismo de la Declaración. ${ }^{94}$ Centrándonos por ahora en el individualismo, se ha de reforzar la idea de que la mitología iluminista concibió al hombre de un modo deshumanizante: lo imaginó cual ente aislado, unidad de medida aritmética, a fin de construir sobre dicha base uniforme la nueva sociedad igualitaria. De ahí el nuevo sujeto de derechos: el individuo universal y no la persona singular. El sujeto de los derechos humanos es,

de edad. A estos pertenece el "vulgo", es decir, las mujeres en general, los sirvientes, los obreros, los campesinos y los "salvajes", los cristianos y los judíos. El más reciente estudio de esta línea, MARTIN, Xavier, Naissance du sous-homme au coeur des Lumières: les races, les femmes, le peuple (Poitiers, Dominique Martin Morin, 2014).

${ }^{91}$ Las palabras del autor son célebres: "Jindiquerai seulement l' erreur de théorie qui a servi de base à cette constitution, et qui a égaré les Français depuis le premier instant de leur révolution. La constitution de 1795, tout comme ses aînées, est faite pour lhomme. Or, il n'y a point 'homme dans le monde. J ai vu, dans ma vie, des Français, des Italiens, des Russes, etc.; je sais même, grâces à Montesquieu, qu'on peut être Persan: mais quant à lhomme, je déclare ne lavoir rencontré de ma vie; s'il existe, c'est bien à mon insu" : De MaISTRE, Joseph, Considérations sur la France, cit. (n. 22), p. 50.

${ }_{92}$ "Han reducido a los hombres a meras fichas sueltas, solo para efectos de contabilidad [...]"; "Los pretendidos derechos de que hablan estos teorizadores [...] en la misma medida que son metafísicamente correctos, son moral y politicamente falsos [...]"; "Esa perfección asbtracta es su defecto práctico. Teniendo derecho a todo, se quiere todo": Burke, Edmund, Reflexiones sobre la Revolución Francesa, cit., (n. 109), pp. 272, 107, 104.

93 "Ils sont, comme la femme, des "promesses qui ne peuvent être tenues" (disait Paul Claudel) ou (comme disait notre économiste Jacques Rueff de la monnaie américaine) : de "fausses créances" qu'il est impossible de payer. Et les fausses promesses provoquent... la peine de "Lattente trompée ". Les fausses promesses suscitent des vagues de revendications sans issue. En bon langage, il serait de lessence du droit de pouvoir être revendiqué - la revendication satisfaite. Ici, les revendications ne peuvent être satisfaites. Les droits de Phomme sont des illusions [...]. Leur tort est de promettre trop": VILLEY, Michel, Le droit et les droits de l homme (París, Presses universitaires de France, 1983), p. 11.

${ }^{94}$ Gentile, Francesco, Intelligenza politica e ragion di Stato, cit. (n. 64), p. 74. 
desde ahora, un ser humano inexistente: el individuo abstracto, sin diversificación antropológica, sin herencia, pasado o historia, sin lazo familiar, asociativo, moral o religioso, naturalmente acreedor y no deudor. Son, de acuerdo a la metáfora de Grossi, todos iguales en el plano del derecho como estatuas que han salido de un mismo molde, como seres solitarios dentro de una única macro-comunidad, el Estado ${ }^{95}$. De ahí el odio de la Revolución a los cuerpos intermedios: "anéantissement" proclama la Ley Le Chapelier, aniquilación, cancelación absoluta de toda estructura asociativa que no provenga del Estado revolucionario, representante necesario de la soberanía nacional ${ }^{96}$.

$\mathrm{El}$ individualismo iluminista es absurdo, nota Segovia. Es el intento de "resolver la realidad hasta llegar al individuo", abstrayendo de éste solo las notas que se consideran relevantes para, en un segundo momento, componer (inventar) una sociedad integrada por los individuos así pensados. "Se trata de una abstracción selectiva -pero radical-, descartando o postergando otros elementos de la condición humana"

b) La Declaración recompone el espacio político, social y económico, volviendo anti-tética la cultura política moderna: "En el mundo moderno, expresa Solari, el problema político deviene en constitucional, porque se trata de hacer coexistir términos antitéticos como la libertad y la autoridad, y de crear el Estado sin el sacrificio de la libertad del individuo"98.

Y es que la Declaración de 1789 no sólo tiene una preocupación "protectora" de los derechos individuales, sino también "fundadora" del poder en relación a los individuos, convertidos en ciudadanos ${ }^{99}$. Conceptualmente, el individualismo conduce al contractualismo y el contractualismo a la formación del Leviatán, el nuevo Estado revolucionario (que, con el tiempo, se transformará en el Estado "laico" y "nacional"). El hombre de los derechos humanos es el hombre de la razón pura, sin determinaciones ajenas a su voluntad. Es el hombre de la "tabla rasa" que pacta desde la nada la construcción de una nueva sociedad. Una gran impostura, co-

${ }^{95}$ Grossi, Paolo, Europa y el derecho (Traducción de Luigi Giuliani, Barcelona, Crítica, 2008), p. 115.

${ }^{96} \mathrm{La}$ normativa originaria que prohíbe las libertades asociativas y demás del mismo género es del 4 de agosto de 1789. Junto a la Declaración de 1789, la feroz interdicción es incluida en el preámbulo de la Constitución de 1791.

${ }^{97}$ Segovia, Fernando, Derechos humanos y constitucionalismo (Madrid, Marcial Pons, 2004), p. 23.

${ }^{98}$ SOLARI, Gioele, La formazione storica e filosofica dello Stato moderno (4a edición, Napoli, Guida, 2000) p. 64.

${ }^{99}$ Gauchet, Marcel, Derechos del hombre, cit. (n. 20), p. 561. 
menta Furet ${ }^{100}$. Es el hombre que monta el Estado al albur de fórmulas geométricas, como duramente reprocha Taine ${ }^{101}$.

Desde esta perspectiva los derechos humanos, en su carácter racionalista y abstracto, quedan al servicio de la rearticulación del poder inmenso del Estado moderno y de la succión o eliminación de todos los poderes extraestatales. Esta ecuación desequilibrante entre individuo y Estado encuentra su mejor fórmula en el artículo 4 de la Declaración ${ }^{102}$. Soporte de la voluntad colectiva, el Estado es el único ente legitimado para reconocer los derechos individuales. En esta dinámica, la transmutación de la persona en individuo facilita su posterior reabsorción por el Estado moderno.

En la lógica de su radicalización, el artículo citado muestra la "proscripción metódica del principio de la personalidad", latente en toda la Declaración ${ }^{103}$. Como la afirmación de los derechos individuales implica la reconstrucción de un nuevo escenario político que va a convertir a esos individuos en ciudadanos, base de la felicidad prometida, el Estado es quien se encarga de redefinir las políticas que llevan a esa felicidad, puesto que se define a sí mismo como el representante de todos los individuos integrados en la hipóstasis "voluntad general" 104 o "nación" 105.

c) La recomposición política conlleva la recomposición jurídica. A partir de la Declaración se inicia "la reducción completa del 'droit' a un conjunto de 'lois". Lo que durante el siglo XIX conducirá al legalismo,

${ }^{100}$ La ilusión de la "tabla rasa" inherente a la idea revolucionaria, expresa el constructivismo espontáneo de la opinión en la época democrática, su tendencia a imaginar lo social como simple producto de la voluntad. FURET, Francois, Le passé d une illusion, cit. (n. 9), p. 52.

101 "Aplicad el contrato social si os parece bien, pero no lo apliquéis sino a los hombres para quienes está hecho. Son hombres abstractos que no pertenecen a ningún tiempo, lugar o pais. Puros entes nacidos de exigencias filosóficas [...]. Un extracto de naturaleza humana [...] independientes, iguales, sin pasado, sin padres, sin compromisos, sin tradiciones, sin hábitos, como otras tantas entidades aritméticas, todas separables, todas equivalentes": TAINE, Hipólito, Los orígenes de la Francia Contemporanea (Traducción Luis Terán, Madrid, España Moderna), II, p. 67

${ }^{102}$ Déclaration des droits de l homme et du citoyen de 1789, artículo 4:"La liberté consiste à pouvoir faire tout ce qui ne nuit pas à autrui: ainsi, Pexercice des droits naturels de chaque homme n'a de bornes que celles qui assurent aux autres membres de la société la jouissance de ces mêmes droits. Ces bornes ne peuvent être déterminées que par la loi" ().Texto original en el sitio del Conseil Constitutionnel.

${ }^{103}$ GAUCHET, Marcel, La Révolution des droits de l'homme, cit. (n. 23), p. 119.

${ }^{104}$ Déclaration des droits de l homme et du citoyen de 1789, artículo 6 :" La loi est lexpression de la volonté générale".

${ }^{105}$ Ibíd., artículo 3:" Le principe de toute souveraineté réside essentiellement dans la Nation". (Art.3). 
al despotismo legal, hasta llegar a la "legolatría" ${ }^{106}$. La razón es clara y está contenida en la propia Declaración: no puede ser sino bueno lo que manda la ley. No porque su contenido sea justo, sino porque representa la voluntad general.

A este propósito hay que observar que en la Declaración no aparece la noción de bien común, en su sentido propio: ha sido reemplazada por la categoría de "bien público", "utilidad pública" o "seguridad nacional". El bien común remite al bien de la persona buscado, compartido y difundido en comunidad, según la conocida fórmula de Francisco de Vitoria. El "bien público”, en cambio, redirige a la utilidad del Estado en construcción o en expansión. Como máximo instrumento colectivo de representación abstracta, es a la ley a quien corresponde definir o delimitar la utilidad pública. A través de ella se convierte todo orden jurídico en un orden normativo emanado del poder estatal.

\section{La "Declaración" de 1789 y el ideal emancipatorio de la modernidad.}

La Declaración adopta una noción de libertad no finalizada, puramente negativa, que implica el rechazo de aquella dimensión de la realidad que la doctrina clásica llama ley divino-natural y sus determinaciones históricas en la familia y otras formas de asociatividad comunitarias.

Las libertades y derechos de la Declaración se alimentan de la filosofía iluminista de la emancipación. Empero, en la visión conservadora, la emancipación es ambigua y ha dado paso en los dos últimos siglos a modalidades divergentes. Por un lado, el liberalismo adoptó la emancipación individual como principio de organización política, solo limitada, en teoría, por igual pretensión de otros individuos. Por su parte, la democracia igualitaria en sus diversas formas siguió la veta rousseauniana de la emancipación colectiva, pretendiendo el compromiso total, en la vida pública y privada, del ciudadano con el Estado.

Donoso Cortés advirtió acerca de esta alternancia que veía concluir en un fatal sometimiento del individuo ${ }^{107}$. Para Arendt es la gran paradoja de la emancipación moderna, latente ya en la Declaración $n^{108}$. Caído, sin embargo, el muro de Berlín, y las pretensiones del racionalismo político

${ }^{106}$ Grossi, Paolo, Europa y el derecho, cit. (n. 121), p. 115.

${ }^{107}$ Carta al Conde de Montalembert (26 de mayo de 1849), en Donoso CorTés, Juan, Obras de don Juan Donoso Cortés, ordenadas por don Gavino Tejado (Madrid, Tejado, 1854), III, pp. 278-279.

${ }^{108}$ ARENDT, Hannah, Los orígenes del totalitarismo (traducción de Guillermo Solana, Taurus, Madrid), pp. 368-369. 
en general ${ }^{109}$, la modernidad solo parece conducirse por la vía de la emancipación individual.

El íter de esta emancipación, desde la Declaración a nuestros días, ha sido suficientemente interpretado, con sus singularidades, por el pensamiento liberal. Pero el nudo de esta concepción así como su desenvolvimiento ha sido objeto de una aguda contestación por parte del pensamiento conservador.

Las objeciones se plantean desde los inicios. En los mismos días en que se difunde la Declaración, el magisterio pontificio de la Iglesia Católica se apresura a rechazar la doctrina emancipatoria que la inspira ${ }^{110}$. Es un repudio continuo que permanece en el tiempo, de un modo explícito, al menos hasta el Concilio Vaticano $\mathrm{II}^{111}$. El rechazo fomenta la reacción anti-liberal del neotomismo, del tradicionalismo, y de la doctrina social católica en general.

Es frecuente encontrar análoga impugnación en el conservadurismo anglosajón, al menos en los maestros de su sedimentación históricodoctrinaria ${ }^{112}$.

Es trazo común del conservadurismo acusar de utopismo gnóstico o de ilusión ideológica al ideal emancipatorio de la modernidad. La razón individual no es ni omnisciente ni omnipotente, por lo que su pretensión de construir o crear una sociedad nueva, prescindiendo de la naturaleza humana, del logos y del cosmos, conduce siempre al desastre ${ }^{113}$.

Segovia analiza en dos etapas la raíz ideológica de este constructo. La primera, corresponde a aquella antropología liberal de los siglos XVIII y XIX, que exalta al sujeto abstracto, sin cuerpos asociativos naturales, sin desigualdades reales ni potenciales, dueño de sí mismo (self ownership), abierto a poseer el mundo externo mediante la ilustración y el trabajo. Se da por descontado que el ser humano es siempre racional y que no elige sino que decide. Sus derechos remiten a la estructura básica de un individuo autosuficiente: ser libre es carecer de obstáculos para expandir la posesión de sí y del entorno.

${ }^{109}$ Sobre este punto interesantísimo: Grasso, Pietro Giuseppe, El problema del constitucionalismo, cit. (n. 63), pp. 88-102.

${ }^{110}$ Pío VI, "Breve al cardenal de La Rochefoucauld y a los prelados miembros de la Asamblea Nacional”, en El Mismo, Brefs et instructions de notre Saint Pére le Pape Pio VI depuis 1790 jusq'au 1796 (Roma, 1798), I, pp. 97-98.

${ }^{111}$ Alvear Téllez, Julio, La libertad moderna de conciencia y de religión (Madrid, Marcial Pons, 2013), pp. 243-298.

${ }^{112}$ Por todos, NisBET, Robert, La formación del pensamiento sociológico, cit. (n. 2), passim; KIRK, Russell, Un programa para conservadores (Traducción de Rogelio de Castro, Madrid, Rialp, 1957), passim.

${ }^{113}$ Castellano, Danilo, Racionalismo y derechos humanos, cit. (n. 75), p. 23. 
En la segunda mitad del siglo XX, el proceso de liberación concluye. El hombre queda solo con su individualidad, desligado de sus vínculos socio-naturales o de las estructuras fuertes de los cuerpos intermedios. Es tiempo para la segunda etapa, que es la contemporánea. Aquí, la lógica emancipadora de los derechos se vuelve contra las propias estructuras de la modernidad: el Estado nacional, la representación democrática y la constitución como molde de conducta general. Es la etapa nihilista, donde la identidad individual o colectiva no es algo dado, sino en interminable producción. Es la "heterotopía", donde el ser se diluye. Cada individuo se construye según un proyecto cualquiera (la razón ya no es parámetro). Los derechos humanos no son más que instrumentos jurídicos de la ciclópea redefinición identitaria, ante la cual el Estado y el régimen representativo se ven forzados a redefinirse ${ }^{114}$.

Se plantea aquí una ulterior interrogante. Si la exaltación del sujeto parece terminar en su disolución, ¿hasta qué punto son jurídicos los derechos del hombre que la canalizan? Al respecto, se ha sostenido que la concepción moderna de los derechos subjetivos, en cuanto se fundan en una pura subjetividad auto-referente, y no en el presupuesto ontológico de un orden justo determinado, da lugar a pretensiones, y no propiamente a facultades jurídicas ${ }^{115}$. Al fin y al cabo, como ha sostenido Guzmán Brito, si la juridicidad depende de una actitud intramental del titular, de un conocimiento o percepción suya acerca de lo que sea bueno o justo, no hay mayor diferencia entre saturación ideológica ("filosofismo") y derecho ${ }^{116}$.

\section{CONCLUSIONES}

\section{Concluimos:}

$1^{\circ} \mathrm{La}$ Déclaration des droits de l'Homme et du Citoyen expresó, desde su génesis, un relevante valor simbólico. Los ideales iluministas de la libertad y la igualdad reconocidos como derechos de alcance universal; el pacto

${ }^{114}$ Segovia, Fernando, Derechos humanos y constitucionalismo, cit. (n. 23), pp. 30-35, 54 y 85-93. Desde otra mirada, GAUCHET, Marcel, La religión en democracia. El camino del laicismo (Madrid, Editorial Complutense, 2003), pp. 77-85.

${ }^{115}$ Castellano, Danilo, Quale diritto? Su fonti, forme, fondamento della giuridicita (Napoli, Edizioni, Scientifiche Italiane, 2015), pp. 135-138. Reivindicando la tesis clásica, el autor opone la exclusiva reivindicación de efectividad de la pretensión a la racionalidad esencial de la facultad jurídica. El poder es siempre racional, esto es, ejercitado conforme a la naturaleza de la cosa y a su fin.

${ }^{116}$ GuZMÁn Brito, Alejandro, Historia de la denominación del derecho-facultad como subjetivo, en Revista de Estudios Histórico-Jurídicos, 25 (2003), leído en http:// www.scielo.cl/scielo.php?script=sci_arttext\&pid=S0716-54552003002500011\&ln $\mathrm{g}=\mathrm{es} \& \mathrm{nrm}=\mathrm{iso} \& \mathrm{t} \operatorname{lng}=\mathrm{es}$, consultada el 15 de noviembre de 2015 . 
social en cuanto fuente exclusiva de la sociedad y del Estado; la democracia girondina o jacobina, imagen del triunfo de la voluntad popular sobre toda forma de despotismo o de vínculo no consentido; la lógica de la emancipación como paradigma de la dignidad y de los derechos individuales.

En contrapeso, la Declaración alcanzó escaso valor jurídico. No fue aprobada por la Asamblea Nacional. Solo es incorporada en la Constitución de 1791, para ser rápidamente sustituida en 1793. Durante la década revolucionaria se violarán como nunca los derechos y libertades consagrados en ella. Habrá que esperar siglo y medio para que la Declaración vuelva a ser reconocida constitucionalmente, en la carta francesa de 1946.

$2^{\circ}$ El pensamiento conservador, en la medida en que se articula en torno a la Contra-Revolución, cuestiona desde sus inicios el significado político y jurídico de la Declaración, advirtiendo que tras una aparente neutralidad en la formulación de los derechos y las libertades, late una concepción del hombre, de la sociedad y del mundo altamente perjudicial para la comunidad política. La contestación se extiende, en general, a toda la Revolución Francesa, considerada como filosofía, movimiento histórico y herencia política.

$3^{\circ}$ La lectura conservadora se despliega en varias direcciones complementarias:

a) En el rechazo a la formulación misma de los derechos del hombre, que en su a-temporalidad idealista y su individualismo, no reconoce la estructura de los cuerpos intermedios y desprotege a las personas reales, inmersas en relaciones de justicia concretas y deudoras de lazos comunitarios vitales.

b) En el develamiento del significado total de la ideología de la libertad y la igualdad, que convierten en antitético todo el marco de la política moderna, varado entre la disolución individualista y la democracia rousseauniana tendente al Estado total.

c) En la crítica al secularismo que permite utilizar los derechos del hombre como coartada para eliminar al Dios cristiano de la vida política y social, y disponer así, a voluntad, del orden jurídico, sin referencias a ninguna norma trascendente.

d) En la crítica al racionalismo político que pretende construir ex novo y geométricamente los lazos humanos con los parámetros del pensamiento abstracto y deductivo, con ilusorio desprecio por el orden histórico y natural, en cuanto no enteramente disponible.

e) En la denuncia a la antropología liberal, que simplifica la realidad poliédrica del ser humano, atribuyendo derechos a un individuo imaginario, a-social, desarraigado, pulcramente racional y utópicamente autosuficiente.

f) En el rechazo al ideal ilustrado de la emancipación, cuya lógica ha 
llevado a convertir los derechos individuales en instrumentos de disolución del propio sujeto, y de perversión del tejido social.

Proyectando esta línea argumental a nuestros días, es indudable que materialmente la Declaración de 1789, como las cartas que le han sucedido en contenido, otorgan espacios jurídicos para desenvolver legítimos derechos de la persona humana. El problema radica en el método de su formulación y, más hondamente, en la filosofía o doctrina que sustenta estas libertades y derechos, en virtud de la cual su fundamento y su fin -y a veces su objeto inmediato- quedan vinculados a una concepción unilateral del hombre y de la sociedad política.

\section{BIBLIOGRAFÍA}

Alvear Téllez, Julio, La Revolución Francesa: el legado de descristianización y violación de los derechos fundamentales, en VV. AA., Revisión del legado jurídico de la Revolución Francesa en las Américas (Santiago, Ediciones Universidad Bernardo O’Higgins, 2013).

Alvear Téllez, Julio, La libertad moderna de conciencia y de religión (Madrid, Marcial Pons, 2013).

ArChives numériques de la Révolution franÇAISE, Archives Parlementaires (Edición on line) VIII y XII. Consultada en: (http://frda.stanford.edu/fr/ap).

ARENDT, Hannah, Los orígenes del totalitarismo (traducción de Guillermo Solana, Taurus, Madrid).

Baecque, Antoine de - Schmale, Wolfgang - Vovelle, Michel, L'An I des droits de l'homme (París, CNRS, 1988).

BASSE, Bernard, La constitution de l'ancienne France. Principes et lois fondamentales de la Royaute Francaise (Paris, Les Presses Saint Louis, 1973).

Belloin, Gerard, Entendez-vous dans nos memoires? Les Français et leur Revolution (Paris, La Decouverte, 1988).

Beruin, Isaiah, La traición de la libertad. Seis enemigos de la libertad humana (México, Fondo de Cultura Económica, 2004).

BerLIn, Isaiah, The Proper Study of Mankind (New York, Farrar, Strauss and Giroux, 1998).

BobBio, Norberto, El tiempo de los derechos (traducción de Agustín de Asís, Madrid, Sistema, 1991).

Cantero, Estanislao, La contaminación ideológica de la historia. Cuando los hechos no cuentan (Madrid, Libros Libres, 2009).

CASTELlano, Danilo, Quale diritto? Su fonti, forme, fondamento della giuridicita (Napoli, Edizioni Scientifiche Italiane, 2015).

Castellano, Danilo, Racionalismo y derechos humanos. Sobre la anti-filosofía políticojurídica de la "modernidad" (Traducción de Coral García, Madrid, Marcial Pons, 2004).

Clement, Marcel, Réflexions sur la Révolution, en EsQuier, Genevieve, Une histoire chrétienne de la Révolution Francaise (Paris, Escalade, 1989).

Совв, Richard, La protestation populaire en France (1789-1820) (Paris, Agora, 1989). 
Compagnon, Antoine, Los antimodernos (Traducción de Manuel Arranz, Barcelona, Acantilado, 2008).

Constant, Benjamin, Ecrits politiques (Paris, Gallimard, 1997).

Constant, Benjamin, Selección de textos politicos (compilador y traductor Oscar Godoy), en Estudios Públicos, 29, (invierno de 1995).

Constant, Benjamin, Cours de politique constitutionnelle (Paris, Guillaumin, 1861), I.

Corrêa de Oliveira, Plinio, O centro do mundo, en Legionário, 490 (1 de fevereiro de 1942).

Corrêa de Oliveira, Plinio, A Nota da Semana, en O Século, 17 de julho de 1932.

CorrêA de Oliveira, Plinio, Nobleza y elites tradionales análogas em las alocuciones de Pío XII al patriciado y a la nobleza romana (2a edición, Madrid, Fernando III, 1995).

Corrêa de Oliveira, Plinio, Révolution et contre-révolution (Préface de S.A.I.R. le prince Dom Pedro Henrique de Orléans e Bragança, Paris, Éditions Catolicismo, 1960).

De Maistre, Joseph, Las veladas de San Petersburgo (Buenos Aires, Espasa-Calpe, 1943).

De Maistre, Joseph, Considérations sur la France (edición on line). Consultada en: http://www.inlibroveritas.net/oeuvres/3134/considerations-sur-la-france

Del Vecchio, Giorgio, Persona, Estado y derecho (Madrid, Instituto de Estudios Políticos, 1957).

Deswarte, Marie-Pauline, La République organique en France (Versailles, Via Romana, 2014).

Donoso Cortés, Juan, Obras de don Juan Donoso Cortés, ordenadas por don Gavino Tejado (Madrid, Tejado Editor, 1854), III.

Dumont, Jean, La Révolution française ou les prodigues du sacrilège (Limoges, Criterion, 1988).

Fabre, Joseph, Les Péres de la Révolution. De Bayle a Condorcet (Paris, Alcan, 1916).

FAYARD, Jean Francois, La justice révolutionnaire. Chronique de la Terrour (Paris, Laffont, 1987).

Ferrajoli, Luigi, Derechos y garantías. La ley del más débil (Traducción de Perfecto Andrés Ibáñez, Madrid, Trotta, 2010).

Forrest, Alan, La Révolution française et les pauvres (Traduit de l'anglais par MarieAlix Revellat, Paris, Perrin, 1986).

FulCONIS, Monique et Michel, La Révolution Francaise dans les manuels scolaires: mensonge o verité (Nice, Serre, 1989).

Furet, Francois - Ozouf, Mona (editores), Diccionario crítico de la Revolución Francesa (traducción de Jesús Bravo y otros, Madrid, Alianza Editorial, 1989).

FurET, Francois, Le passé d'une illusion (Paris, Laffont, 1995).

GAMBRA, Rafael, La monarquia social y representativa en el pensamiento tradicional (Madrid, Rialp, 1954).

GAmbra, Rafael, "Joseph de Maistre y la idea de comunidad" ("Estudio preliminar" en De Maistre, Joseph, Consideraciones sobre Francia, Madrid, Rialp, 1955).

GAUCHET, Marcel, La religión en democracia. El camino del laicismo (Madrid, Editorial Complutense, 2003).

Gauchet, Marcel, La Révolution des Droits de l'Homme (Paris, Gallimard, 1989).

Gengembre, Gérard, La Contre-Révolutión ou l'historie désespérante. Histoire des idées politiques (Paris, Imago, 1989). 
Gentile, Francesco, Intelligenza poitica e ragion di Stato (2a edición, Milano, Giuffrè, 1984).

Goulemot, Jean-Marie, Adieu les philosophes. Que reste-t-il des Lumieres (Paris, Seuil, 2001).

Grasso, Pietro Giuseppe, El problema del constitucionalismo después del Estado moderno (Madrid, Marcial Pons, 2005).

GrAY, John, Las dos caras del liberalismo. Una nueva interpretación de la tolerancia liberal (Paidos, Barcelona, 2001).

Groethuysen, Bernard, Filosofía de la Revolución Francesa (México, Fondo de Cultura Económica, 1989).

Grossi, Paolo, Europa y el derecho (Traducción de Luigi Giuliani, Barcelona, Crítica, 2008).

GuZmán Brito, Alejandro, Historia de la denominación del derecho-facultad como subjetivo, Revista de Estudios Histórico-Jurídicos, 25 (2003). Consultada en: http://www. scielo.cl/scielo.php?script=sci_arttext\&pid=S0716-54552003002500011\&lng=e s\&nrm=iso\&tlng=es)

Hegel, Georg Wilhelm Friedrich, Filosofia da história (Traducción de María Rodrigues y Hans Harden, Brasilia, Editora UNB, 1995).

Hirschman, Albert, Deux siecles de rhétorique réactionnaire (traducción de Pierre Andler, Paris, Fayard, 1991).

Hunt, Lynn en Inventing Human Rights: A History (New York, Norton Company, 2007)

KANT, Immanuel, Ideas para una historia universal en clave cosmopolita y otros escritos sobre filosofía de la historia (Traducción de Concha Roldán, Madrid, 2a edición, Tecnos, 1994).

KIRK, Russell, Un programa para conservadores (Traducción de Rogelio de Castro, Madrid, Rialp, 1957).

Lebrun, Francois y Dupuy, Roger (directores), Les Ressistances a la Revolution (Paris, Imago, 1987).

Marshall, Citizenship and Social Class: And Other Essays (Cambridge, Cambridge University Press, 1950).

Martin, Jean-Clément, La Vendée et la Révolution. Accepter la mémoire pour ecrire l'histoire (Paris, Perrin, 2007).

Martin, Jean-Clément, Contre-Révolution, révolution et nation en France 1789-1799 (Paris, Seuil, 1998).

Martin, Jean-Clément (director), Dictionnaire de la Contre-Révolution (Paris, Perrin, 2011).

Martin, Xavier, Naissance du sous-homme au coeur des Lumières: les races, les femmes, le peuple (Poitiers, Dominique Martin Morin, 2014).

MARX, Karl, Anales franco-alemanes (Barcelona, Martínez Roca, 1970).

Masseau, Didier, Les ennemis des philosophes. L'antiphilosophie au temps des Lumieres (Paris, Albin Michel, 2000).

McMahon, Darrin M., Enemies of the Enlightenment. The French Counter-Enlightenment an the Making of Modernity (New York, Oxford University Press, 2001).

Michelet, Jules, Historia de la Revolución Francesa (Buenos Aires, Argonauta, 1946), I y III.

Miller, David (coord.), Liberty (Oxford, Oxford University Press, 1991).

Montet, Jean-Michel, La Déclaration des droits de l'homme de 1793: apports de la 
lexicologie quantitative aux problèmes de sa genèse, en Langages de la Révolution (1770-1815) (Paris, Institut National de la Langue Francaise, 1995).

Necker, Jacques, Euvres complètes de M. Necker publiées par M. le Baron de Staël, (Paris, Treuttel et Wurtz, 1821).

NisBet, Robert, La formación del pensamiento sociológico (traducción de Enrique Molina, Buenos Aires, Amorrortu, 2009), I.

Nisbet, Robert, Conservadurismo (Traducción de Diana Goldberg, Madrid, Alianza, 1986).

Paine, Thomas, Derechos del hombre (Madrid, Alianza, 1984)

Peces-Barba, Gregorio, Lecciones de derechos fundamentales (Madrid, Dykinson, 2004).

Pichot-Bravard, Philippe, La Révolution Francaise (Versailles, Via Romana, 2014).

Pío VI, Brefs et instructions de notre Saint Pére le Pape Pio VI depuis 1790 jusqu'au 1796 (Roma, 1798), I.

Rials Stéphane (1989): La Déclaration des droits de l'homme et du citoyen (Paris, Hachette, 1989).

Rivarol, Antoine de, Collection des mémoires relatifs a la Révolution Francaise. Mémoires de Rivarol, avec des notes et éclaircissements historiques (Paris, Badouin, 1824).

Robespierre, Maximilien, Oeuvres complètes (Paris, Société des Études Robespierristes, 1967), X.

Rosselli, Carlo, Socialismo libérale (Turin, Einaudi, 1979).

Ruggiero, Guido de, Historia del liberalismo europeo (Traducción de Carlos G. Posada, Granada, Comares, 2005).

Saint-Etienne, Rabaud, Discours et opinions de Rabaut-Saint-Etienne, suivis de ses deux derniers écrits (Paris, Henri Servier, 1827).

Secher, Reynald, Le Génocide Franco-Francais. La Vendée-Vengé (2a edición, París, PUF, 1988).

Sedillot, René, Le cout de la Révolution Francaise (Paris, Perrin, 1987).

Segovia, Fernando, Derechos humanos y constitucionalismo (Madrid, Marcial Pons, 2004).

SkInNER, Quentin, Visions of politics II (Cambridge, Cambridge University Press, 2002)

Soboul, Albert, La Revolución Francesa. Principios ideológicos y protagonistas colectivos (Barcelona, Crítica, 1989).

SOLARI, Gioele, La formazione storica e filosofica dello Stato moderno (4a edición, Napoli, Guida, 2000).

SolÉ, Jacques, Historia y mito de la Revolución Francesa (México, Siglo Veintiuno, 1989).

Sutherland, Donald G., France 1789-1815: Revolution and Counter-Revolution (New York, Oxford University Press, 1985).

TAIne, Hipólito, Los origenes de la Francia Contemporanea (Traducción Luis Terán, Madrid, España Moderna), II.

Tocqueville, Alexis de, L'Ancien régime et la Révolution, en El Mismo, Oeuvres complètes (Paris, Gallimard, 1952).

Tulard, Jean (director), La Contre-Révolution. Origines, histoire, postérité (Paris, Perrin, 2013).

Tulard Jean - Fayard Jean-François - Fierro Alfred, Historia y Diccionario de la Revolución Francesa (Traducción de Armando Ramos, Madrid, Cátedra, 1989).

Veríssimo Serrao, Juaquín - Bullón de Mendoza, Alfonso (director), La ContraRevolución legitimista (Madrid, Editorial Complutense, 1995). 
Viguerie, Jean, Christianisme et révolution: cinq leçons d'histoire de la Révolution Française (Paris, NEL, 2000).

Viguerie, Jean de, Histoire et Dictionnaire du temps des Lumières (Paris, Laffont, 1995).

VILleY, Michel, Le droit et les droits de l'homme (París, Presses Universitaires de France, 1983).

Voegelin, Eric, La nueva ciencia de la política (Traducción de Joaquín Ibarburu, Buenos Aires, Katz, 2006).

Zagrebelsky, Gustavo, Historia y constitución (Traducción de Miguel Carbonell, Madrid, Trotta, 2005).

\section{TEXTOS NORMATIVOS}

Déclaration des droits de l'Homme et du Citoyen, consultado en http://www. conseil-constitutionnel.fr/conseil-constitutionnel/francais/la-constitution/ la-constitution-du-4-octobre-1958/declaration-des-droits-de-l-homme-et-ducitoyen-de-1789.5076.html

Constitution de 1791, 3 et 4 septembre 1791, , consultado en http://www.conseil-constitutionnel.fr/conseil-constitutionnel/francais/la-constitution/la-constitution-du4-octobre-1958/declaration-des-droits-de-l-homme-et-du-citoyen-de-1791-5082. html

Constitution de l'An I, Première République , 24 juin 1793, , consultado en: http:// www.conseil-constitutionnel.fr/conseil-constitutionnel/francais/la-constitution/ les-constitutions-de-la-france/constitution-du-24-juin-1793.5084.html)

Constitution de l'An III, Directoire, 5 fructidor An III, 22 aout 1795, consultado en: http://www.conseil-constitutionnel.fr/conseil-constitutionnel/francais/la-constitution/les-constitutions-de-la france/constitution-du-5-fructidor-an-iii.5086.html

Constitution de l'An VIII, Consulat, 22 frimaire An VIII, 13 décembre 1799, consultado en: http://www.conseil-constitutionnel.fr/conseil-constitutionnel/francais/ la-constitution/les-constitutions-de-la-france/constitution-du-22-frimaire-anviii.5087.html

Charte de 1814, $1^{\text {ère }}$ Restauration, 4 juin 1814, consultado en: http://www.conseilconstitutionnel.fr/conseil-constitutionnel/francais/la-constitution/les-constitutions-de-la-france/charte-constitutionnelle-du-4-juin-1814.5102.html

Acte additionnel aux Constitutions de l'Empire, Cent-jours, 23 avril 1815, consultado en: http://www.conseil-constitutionnel.fr/conseil-constitutionnel/francais/ la-constitution/les-constitutions-de-la-france/acte-additonnel-aux-constitutionsde-l-empire-du-22-avril-1815.5103.html

Charte de 1830, monarchie de Juillet, 14 août 1830, consultado en: http://www. conseil-constitutionnel.fr/conseil-constitutionnel/francais/la-constitution/lesconstitutions-de-la-france/charte-constitutionnelle-du-14-aout-1830.5104.html

Constitution de 1848, II ${ }^{\mathrm{e}}$ République, 4 novembre 1848, consultado en: http:// www.conseil-constitutionnel.fr/conseil-constitutionnel/francais/la-constitution/ les-constitutions-de-la-france/constitution-de-1848-iie-republique.5106.html

Constitution de 1852, Second Empire, 14 janvier 1852, consultado en: http:// www.conseil-constitutionnel.fr/conseil-constitutionnel/francais/la-constitution/ les-constitutions-de-la france/constitution-de-1852-second-empire.5107.html

Lois constitutionnelles de 1875, III ${ }^{\mathrm{e}}$ République, 24, 25 février et 16 juillet 1875 , consultado en: http://www.conseil-constitutionnel.fr/conseil-constitutionnel/ 
francais/la-constitution/les-constitutions-de-la-france/constitution-de-1875-iiierepublique. $5108 . \mathrm{html}$

Loi constitutionnelle du 2 nov. 1945, Gouvernement provisoire, consultado en: http:// www.conseil-constitutionnel.fr/conseil-constitutionnel/francais/la-constitution/ les-constitutions-de-la-france/loi-du-2-novembre-1945-portant-organisationprovisoire-des-pouvoirs-publics. $104265 . \mathrm{html}$

Constitution de 1946, IV République, 27 octobre 1946, consultado en: http:// www.conseil-constitutionnel.fr/conseil-constitutionnel/francais/la-constitution/ les-constitutions-de-la-france/constitution-de-1946-ive-republique.5109.html

Constitution de 1958, Ve République, 4 octobre 1958, consultado en: http://www. conseil-constitutionnel.fr/conseil-constitutionnel/francais/la-constitution/laconstitution-du-4-octobre-1958/texte-integral-de-la-constitution-du-4-octobre1958-en-vigueur.5074.html 
